\title{
Site Effects and Damage Patterns
}

\author{
Dominic Assimaki, ${ }^{a)}$ M.Eeri, Christian Ledezma, ${ }^{\text {b) }}$ \\ Gonzalo A. Montalva, ${ }^{c)}$ M.Eeri, Andres Tassara, ${ }^{d)}$ M.EerI, \\ George Mylonakis, ${ }^{\mathrm{e})}$ M.EERI, and Ruben Boroschek ${ }^{\mathrm{f}}$
}

\begin{abstract}
A set of observations on site effects and damage patterns from the $\mathrm{M}_{\mathrm{w}} 8.8$ Maule, Chile, earthquake is presented, focusing on identification of structural damage variability associated with nonuniform soil conditions and subsurface geology. Observations are reported from: (1) the City of Santiago de Chile (Américo Vespucio Norte Ring Highway, Ciudad Empresarial business park), (2) the Municipality of Viña del Mar, and (3) the City of Concepción, extending over $600 \mathrm{~km}$ along the Chilean coast. Reconnaissance information and ground motion recordings from the megathrust event are combined with site investigation data in the regions of interest. Comparisons against macroseismic observations related to uneven damage distribution from the $\mathrm{M}_{\mathrm{w}} 8.01985$ Valparaíso earthquake are discussed. Complexities associated with identifying the mechanics and underlying physical processes responsible for the manifestation of these effects are elucidated. [DOI: 10.1193/1.4000029]
\end{abstract}

\section{INTRODUCTION}

The moment magnitude $M_{w} 8.8$ Chile earthquake occurred on 27 February 2010 off the coast of Maule, central Chile, at the boundary of the converging the Nazca and the South American plates. The effects of the earthquake were observed over a wide area spanning over $600 \mathrm{~km}$ along the Chilean coast, from Valparaíso in the north to the Araucania region around Temuco in the south. The event generated significant interest in the seismological and earthquake engineering communities, mainly due to the size of the rupture, the vast extent of the earthquake affected zone, and the severity and variety of coseismic phenomena, ranging from coastal uplift, subsidence and tsunami generation, to extensive liquefaction and lateral spreading, structural failure, landslides, and tailing dam failures among many others discussed in detail in companion articles of this issue.

This study investigates the potential role of site effects in the uneven damage distribution documented in several areas along the earthquake-stricken zone, focusing on macroseismic observations in the city of Santiago de Chile, the municipality Viña del Mar, and the city of Concepción, presented in chronological order as documented by the reconnaissance team that departed from Santiago de Chile first toward the north — and successively toward the

\footnotetext{
a) School of Civil and Environmental Engineering, Georgia Institute of Technology, Atlanta GA 30332

b) Pontificia Universidad Católica de Chile, Vicuña Mackenna 4860, Macul, Santiago, Chile

c) Civil Engineering Dept., University of Concepcion, Casilla 160-C, Correo 3, Concepción, Chile

d) Departamento de Ciencias de la Tierra, Universidad de Concepcion, Vistor Lamas 1290, Concepcion, Chile

e) Department of Civil Engineering, University of Patras, Rio, 26500, Greece

f) Universdad de Chile, Santiago, Chile
} 
south - most ends of the rupture zone. Reconnaissance information from the 27 February 2010 event is combined with site investigation data in the regions of interest, as well as macroseismic observations from the $\mathrm{M}_{\mathrm{w}}$ 8.0 1985 Valparaíso earthquake, to identify patterns of structural damage variability associated with nonuniform soil conditions and/or subsurface geology. Results demonstrate the critical role of site conditions in the severity of structural damage caused by large earthquakes, as well as the strong variability and large uncertainty of damage state distribution resulting from the variable nature of the geometry and stratigraphy of sedimentary deposits.

\section{SANTIAGO DE CHILE}

The city of Santiago de Chile is located in the so-called Central Depression, a basin surrounded by the Main and Coastal ranges of the Andes (western $70^{\circ}$ and southern $33^{\circ}$ ). This basin spans $80 \mathrm{~km}$ long and $30 \mathrm{~km}$ wide (Figure 1); it is mainly elongated in the NS direction and is characterized by three main alluvial cones that drain the Andean Cordillera: cones of Colina, Mapocho, and Maipo. Due to the geomorphological setting, the basin is filled with alluvial sediments (Valenzuela 1978), primarily composed by pebbles, gravels, clays, and volcanic ashes (Morales-Jerez 2002). The pebbles and gravels are mainly located in the eastern and southern part of the basin; clayey material is mostly present in the north, whereas a transition zone is encountered in the center of the valley. In the Pudahuel district, a 40-m-thick layer of ashes (Pudahuel ignimbrite, also known as pumices) is known to seat at the top of the sedimentary column. The stiff pumice probably comes from a major eruption of the Maipo volcano, located at around $120 \mathrm{~km}$ to the southeast, at the

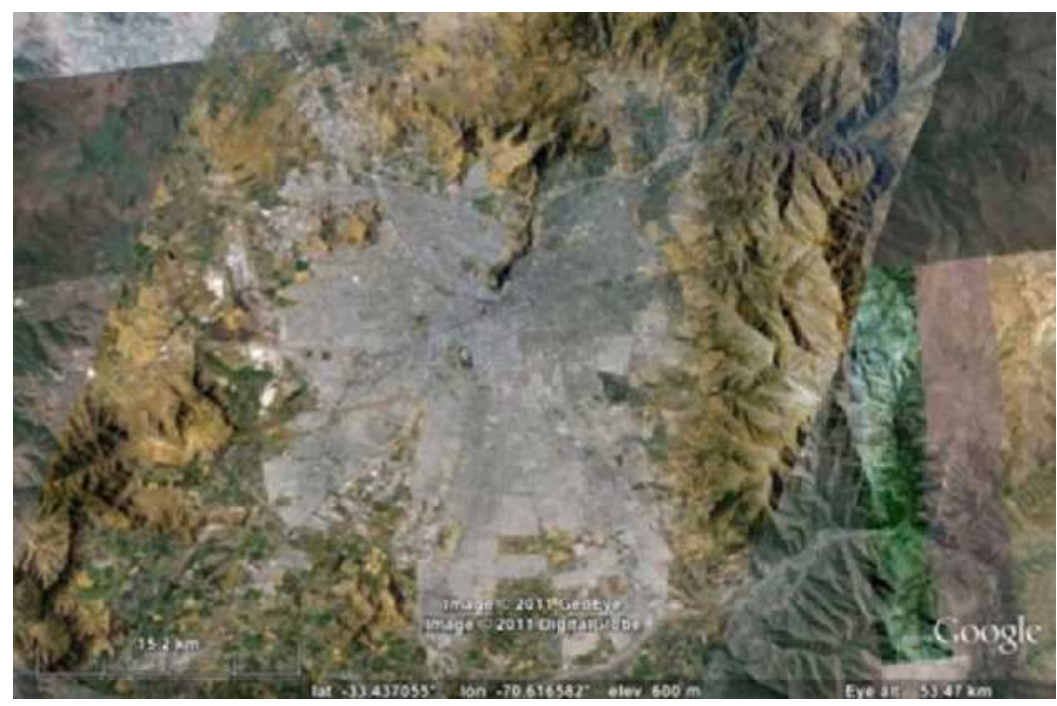

Figure 1. Satellite image of the Santiago $\left(33.4379^{\circ} \mathrm{S}, 70.6498^{\circ} \mathrm{W}\right)$ basin (source: http://eol.jsc.nasa.gov/sseop/images/city/lowres/ISS004/ISS004-E-6990.JPG overlay on Google Earth map) 
Table 1. Mechanical properties (S-wave propagation velocities and densities) at various depths of the three main formations observed in the Santiago basin (gravels, clays, and ashes; after Bravo 1992, Gueguen 1994). Modified from Bonnefy et al. (2008)

\begin{tabular}{llll}
\hline \hline & Depth $[\mathrm{m}]$ & $\mathrm{V}_{\mathrm{s}}[\mathrm{m} / \mathrm{s}]$ & Density $\left[\mathrm{Mg} / \mathrm{m}^{3}\right]$ \\
\hline Gravels & $0-20$ & $480-720$ & $2-2.3$ \\
& 200 & 1300 & 2.1 \\
Clays & $0-20$ & $120-350$ & $1.2-1.8$ \\
& 50 & 550 & 2.1 \\
Ashes & $0-20$ & $180-450$ & $1.15-1.7$ \\
\hline \hline
\end{tabular}

head of the Maipo valley. According to Bravo (1992) and Gueguen (1994), typical mechanical properties of soil deposits in the Santiago basin are listed in Table 1.

The city was shown to be prone to site effects during the $\mathrm{M}_{\mathrm{w}} 8.0$ Valparaíso earthquake in 1985 (Monge 1986), when the seismic intensities (MSK) derived from observed damage to one-story adobe and one story unreinforced masonry houses were reported locally much higher (up to IX) than expected (VI) according to regional intensity attenuation relations (Astroza and Monge 1987, Astroza et al. 1993). The highest intensities were concentrated in areas with poor soils conditions, in the fine-grained alluvial deposit, and in the ashes deposits (Astroza and Monge 1991). Despite this first-order correlation between soil conditions and damage, however, some parts of the most-damaged areas are not built on soft sediments, and some soft sediment areas did not show strong damage during the 1985 earthquake(Fernandez Marescal 2003). These effects were attributed to the geometry of the basin and the geology of deep sediments.

Two examples of damage patterns potentially associated with site effects within the Santiago metropolitan area are described below: (a) four bridges along the northern section of Santiago's ring road, referred to as Américo Vespucio Norte, that showed vast differences in seismic performance during the earthquake and (b) the extensive structural damage documented in Ciudad Empresarial, a recently developed business park northeast of Santiago's downtown, where the first mode of severely damaged high-rise buildings was found to be in agreement with the fundamental period of the soil layers in the area estimated by means of $\mathrm{H} / \mathrm{V}$ ambient noise measurements.

\section{AMÉRICO VESPUCIO NORTE RING ROAD}

Four bridge sites were inspected along Américo Vespucio Norte, the $29 \mathrm{~km}$-long northern section of Santiago's ring road constructed during the period of 2003 to 2006 . The locations of the overpasses are depicted in Figure 2. The damage intensity was highly variable, with two bridges partially collapsing due to unseating (Paso Miraflores and Paso Lo Echevers) and two experiencing only minor structural damage, such as shear key cracking (Paso San Martin and Paso Lo Boza).

Investigating potential correlation between the bridge damage patterns and the underlying soil conditions, the locations of the four inspected bridges are depicted on a geology map of the Santiago Metropolitan Area in Figure 3. The soil conditions at the four bridge sites appear to be similar, characterized by silts and clays of high plasticity, horizontally stratified 


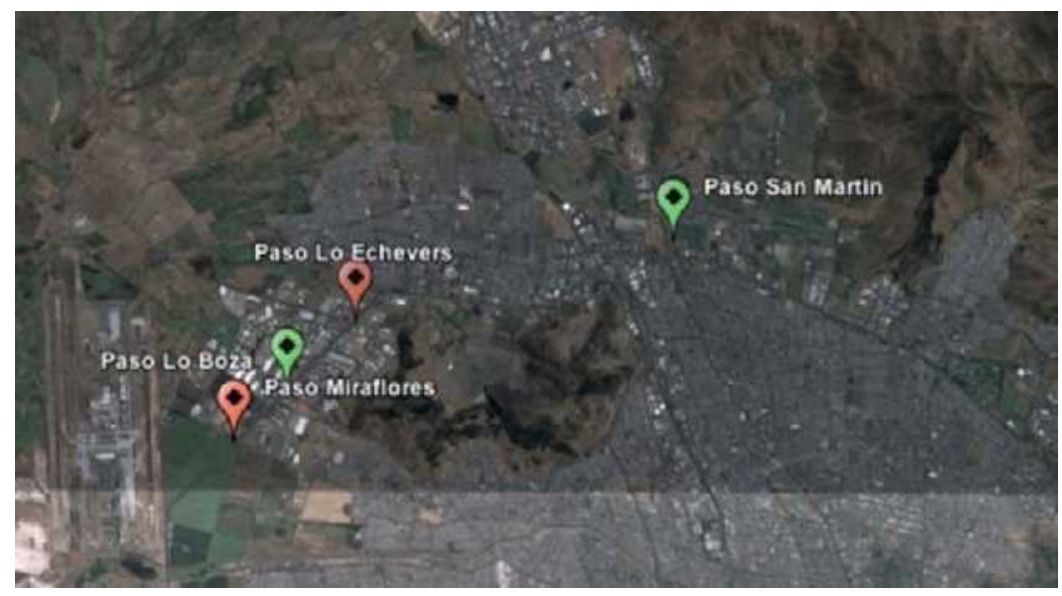

Figure 2. Four Américo Vespucio Ring Road bridges visited during the reconnaissance.

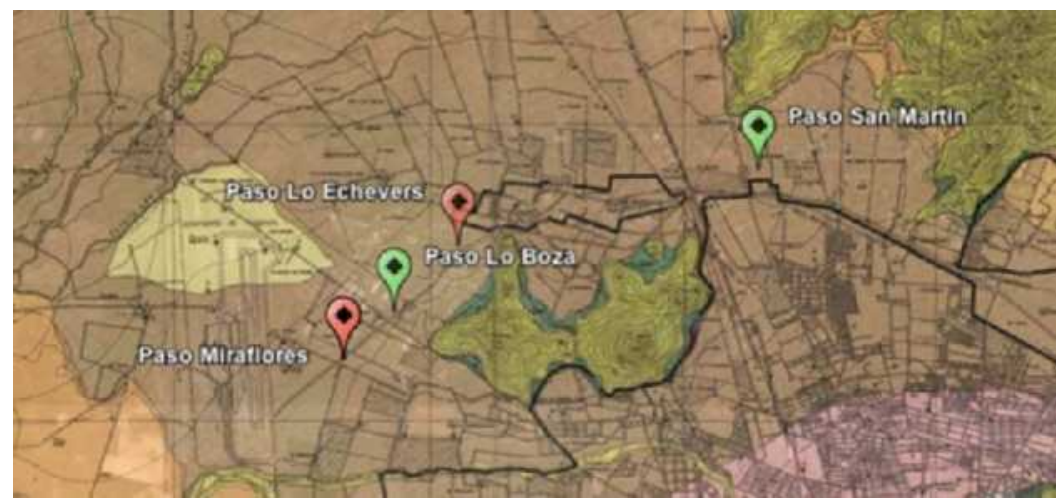

Figure 3. Location of the four bridge sites on the geology map of Santiago Metropolitan Area (Ledezma 2011; approximate map overlay on Google Earth).

as thin interchangeable layers, a soil formation referred to as Finos del Noroeste. According to the NEHRP soil classification system (IBC 2006), the site conditions correspond to Class C or Class D. Figure 4 depicts the locations of the bridge sites on the geological map by Iriarte-Diaz (2003), along with typical NS cross section of the valley geology. The depth to bedrock-basement at the bridge sites, as approximately interpreted from the cross section, does not show clear correlation with the damage states.

More specifically, the bridge of the Paso San Martin overpass $\left(33.3660^{\circ} \mathrm{S}, 70.6891^{\circ} \mathrm{W}\right)$ suffered repairable structural damage, characterized by shear key failures as shown in Figures $5 \mathrm{a}$ and $5 \mathrm{~b}$. Longitudinal and transverse deck movement was also documented, leading to joint damage between the deck segments (Figure 5c). Two pile-diameter-deep excavations conducted as part of the post-earthquake investigation (Figure $5 \mathrm{~d}$ ), revealed no visible 


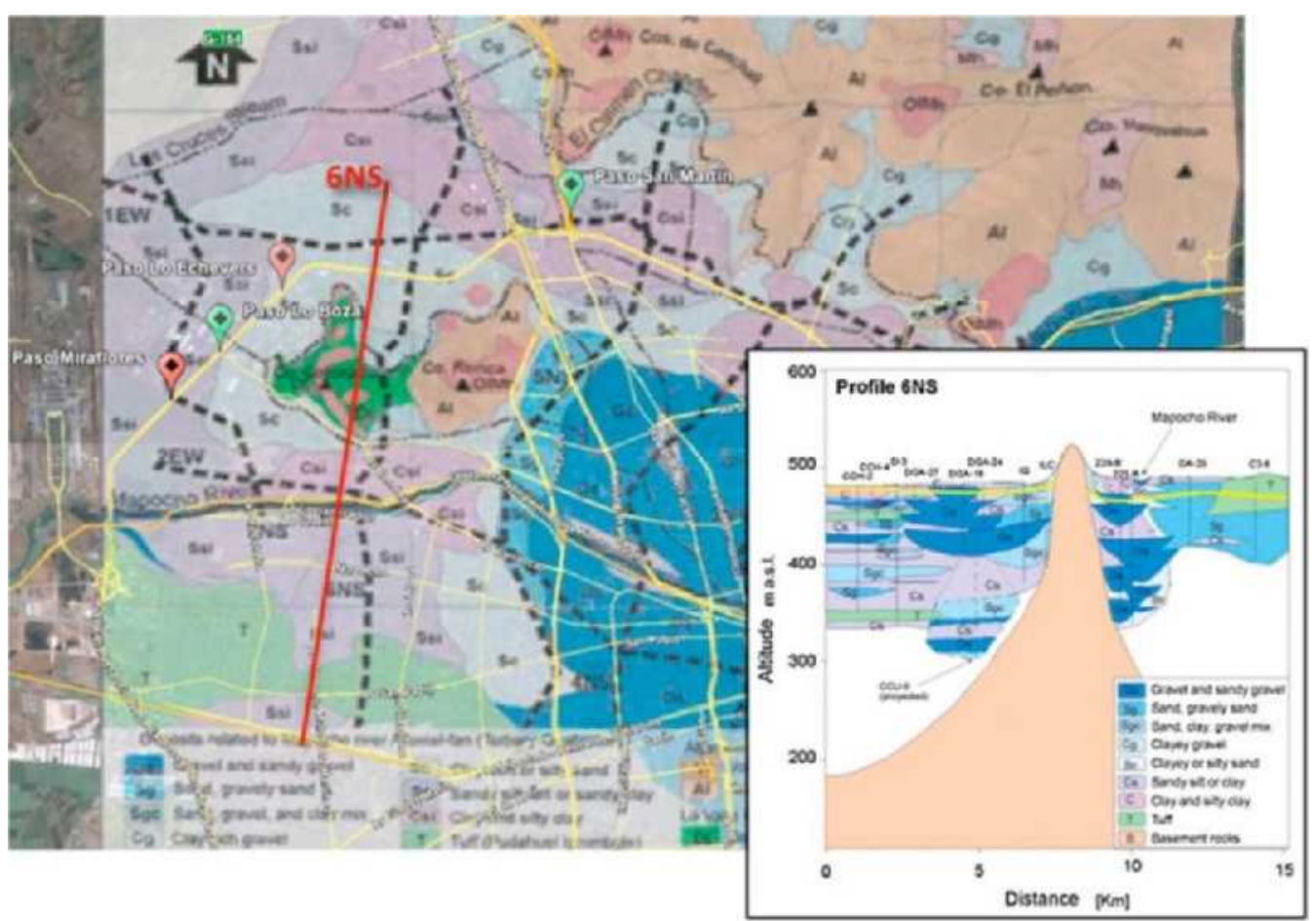

Figure 4. Location of the four bridge sites on the map of geological cross-sections in the NorthWestern part of Santiago de Chile; and geological cross-section along profile 6NS (Iriarte-Diaz, 2003). Paso San Martin (minor damage) is located on clay/silty clay, Paso Lo Echevers (partially collapsed) on clay/silty sand, and Paso Lo Boza (minor damage) and Paso Miraflores (partially collapsed) on sandy silt or silt.

foundation distress. According to the local geology map, the soil profile at the site is clay and silty clay. Similarly, Paso Lo Boza $\left(33.3865^{\circ} \mathrm{S}, 70.7601^{\circ} \mathrm{W}\right)$ suffered minor damage, comprising primarily of shear key failure and subsequent displacement of the deck in the transverse direction (see Figure 7). According to the local geology map, the soil profile at the site is sandy silt. On the other hand, Paso Superior Lo Echevers $\left(33.3759^{\circ} \mathrm{S}, 70.7476^{\circ} \mathrm{W}\right)$ and Paso Miraflores $\left(33.3945^{\circ} \mathrm{S}, 70.7700^{\circ} \mathrm{W}\right)$ suffered severe damage, including collapse of the highway deck (see Figures 6 and 8), while founded on soils very similar to the ones described above, namely clayey/silty sand at the former and sandy silt at the latter. Sitespecific geotechnical data collected at the locations of the four bridges that were inspected during reconnaissance are shown in Figure 9. More specifically, detailed soil profiles are depicted for Paso San Martin (Figure 9a), Paso Lo Echevers (Figure 9b), and Paso Miraflores (Figure 9c), while SPT blow counts and unconfined compression strength $\left(q_{u}\right)$ data at the four locations are compared in Figure 9d.

Given that soil conditions, including depth to bedrock-basement and foundation type (for the most part shallow foundations) at the piers of the four bridges appear only slightly 


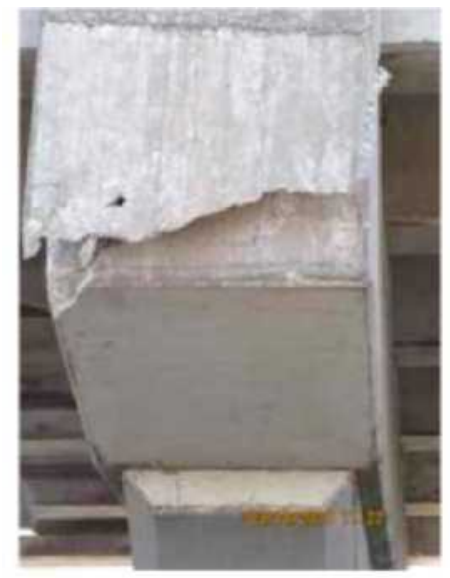

(a)

(c)

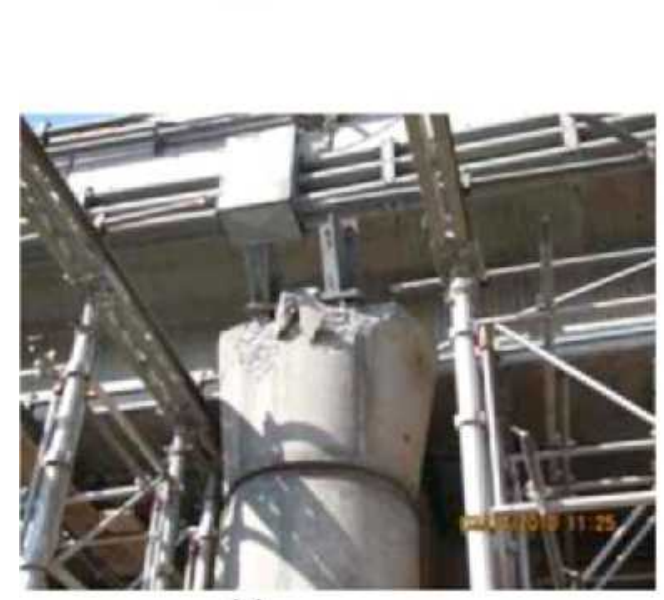

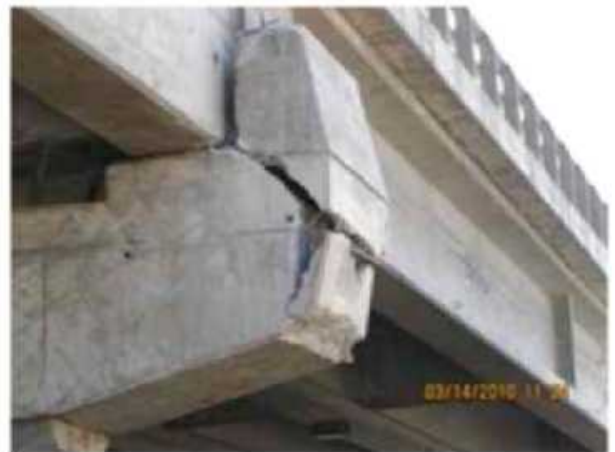

(b)

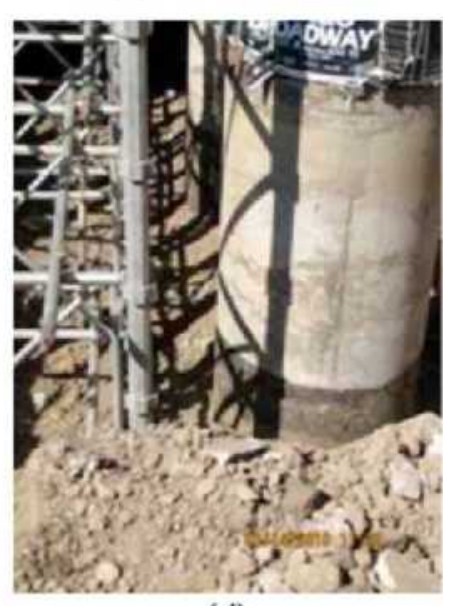

(d)

Figure 5. Paso San Martin (33.3660 ${ }^{\circ} \mathrm{S}, 70.6891^{\circ} \mathrm{W}, 1122 \mathrm{hrs}$ on $\left.03 / 14 / 2010\right)$. Shear key failure and longitudinal, transverse deck displacement.

variable, the question as to what contributed to the highly variable damage along the Américo Vespucio Norte highway remains open. Commenting on damage patterns of the 1985 Valparaíso earthquake, Fernandez Mariscal (2003) noted that variability within small distances not attributed to differences in the construction type or site effects, could be associated with the geometry of the basin and the geology of deep sediments. On the other hand, seismic demand levels in terms of displacement during the mainshock far exceeded in some cases the design code provisions for the foundation soils prevailing in the area. As a result, slight variations in the seismic response of foundation-structure systems with very limited allowance to accommodate displacement capacity beyond the seismic code provisions, would naturally lead to highly variable damage levels. Further investigation is required, therefore, to test the alternative hypotheses explaining the Santiago ring road case-study, comprising structural 


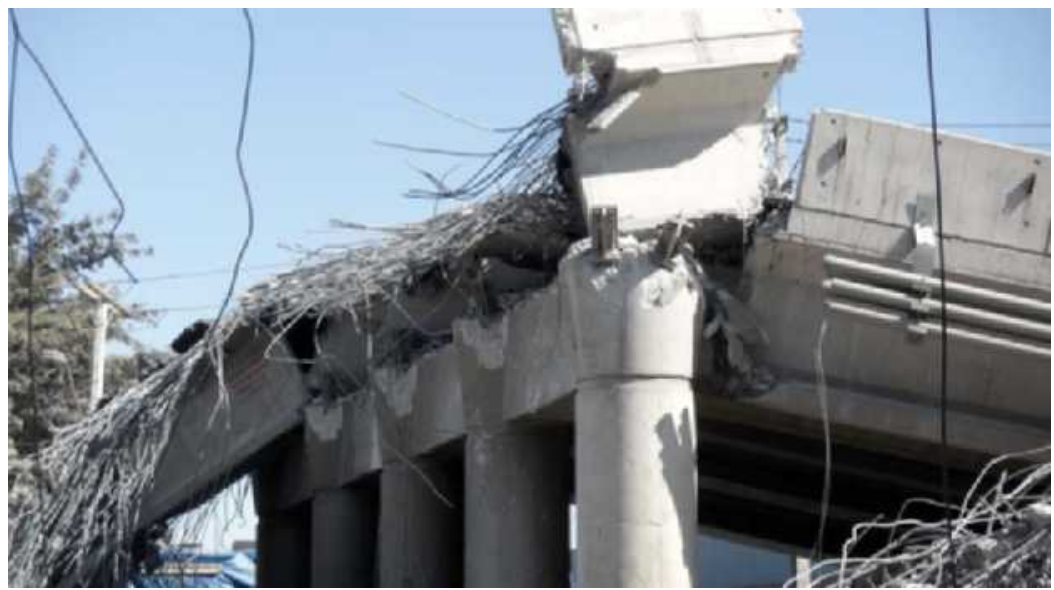

Figure 6. Paso Superior Lo Echevers $\left(33.3759^{\circ} \mathrm{S}, 70.7476^{\circ} \mathrm{W}\right)$. Collapse of the eastbound deck of the Américo Vespucio Norte ring road (Dr. Roberto Leon, personal communication).

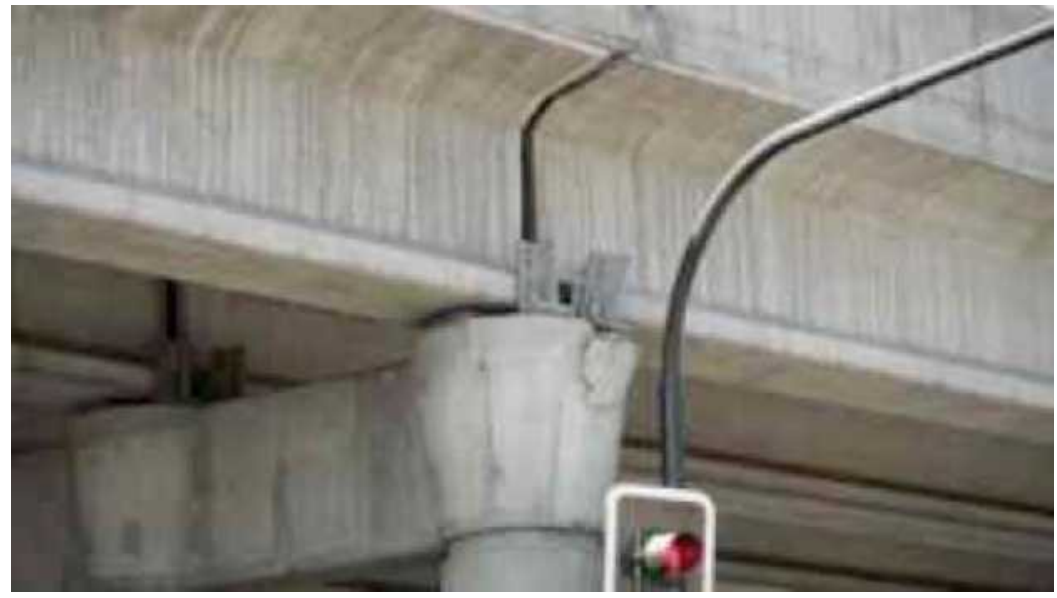

Figure 7. Paso Lo Boza $\left(33.3865^{\circ} \mathrm{S}, 70.7601^{\circ} \mathrm{W}\right)$. Minor structural damage of shear keys (Source: Dr. Roberto Leon, personal communication).

performance studies and as well as a more detailed mapping of the near surface stratigraphy and 2D-3D geometry of the subsurface.

\section{CIUDAD EMPRESARIAL}

Ciudad Empresarial, a 155-acre business park in concentric urban layout that hosts multiple corporate headquarters, is located NE of Santiago downtown. The soil conditions in the area comprise primarily eroded slope material with a shallow water table. Similarly to the 

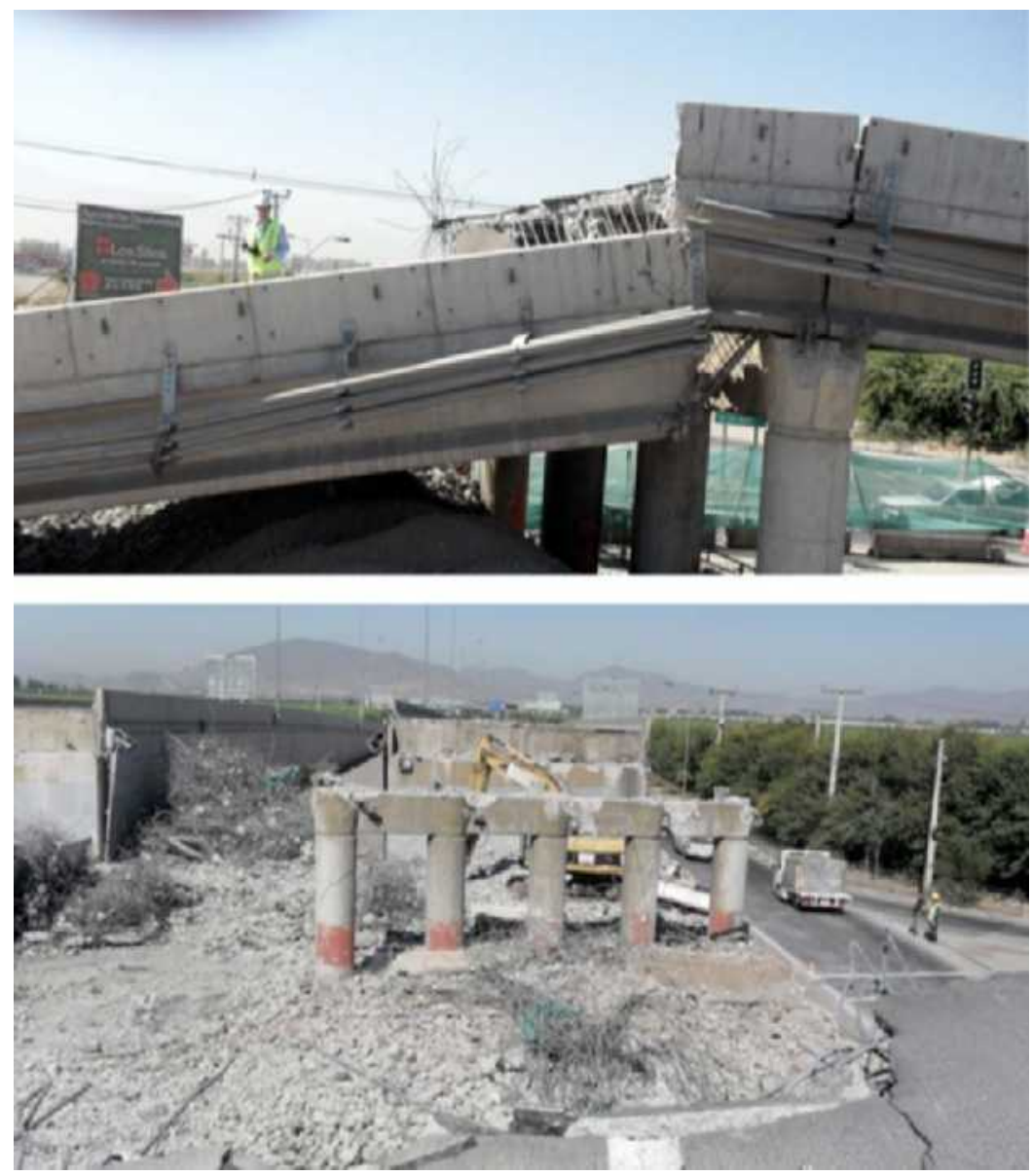

Figure 8. Paso Miraflores $\left(33.3945^{\circ} \mathrm{S}, 70.7700^{\circ} \mathrm{W}\right)$. Deck collapse detail (Source: Dr. Roberto Leon, personal communication).

Américo Vespucio Norte sites, the geologic map classification of the material is Finos del Noroeste $\left(\mathrm{Q}_{\mathrm{fno}}\right)$, namely horizontally stratified thin interchangeable layers of silts and clays of high plasticity. The park comprises highrise buildings that suffered extensive damage during the earthquake, and macroseismic observations at the site were associated with possible site effects. Figure 10 shows an aerial view of the business park, and Figures 11 and 12 depict selected sites visited during the reconnaissance.

Overall, the business park was severely damaged, with 7 buildings that failed and were closed to the public. No total collapse was documented and no casualties were reported at the site, while the only surface evidence of soil deformation observed at the site is shown in Figure 11b. The damaged structures ranged from 5- to 12-stories high, which to first approximation corresponds to $0.5-1.2 \mathrm{sec}$ resonant periods $(0.8-2 \mathrm{~Hz})$. To investigate the potential 


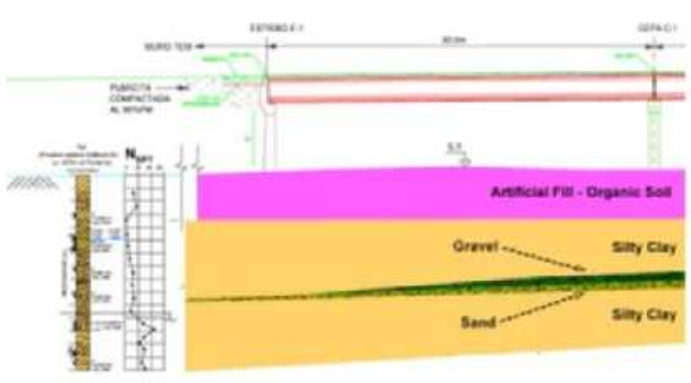

(a)

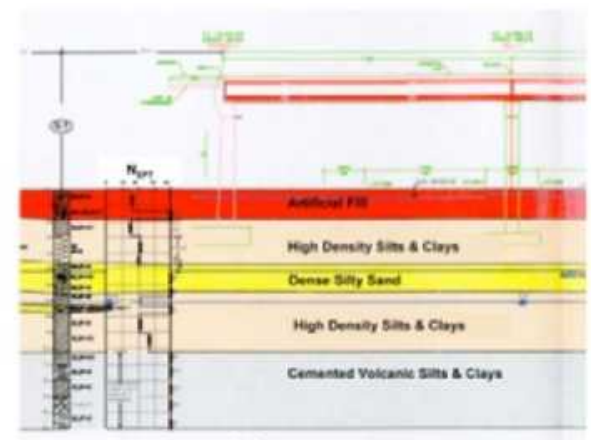

(c)

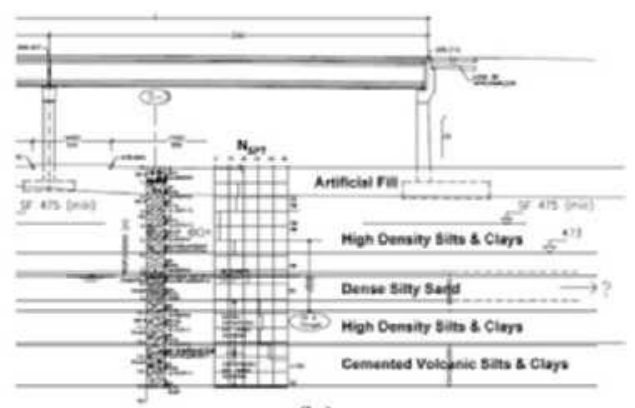

(b)

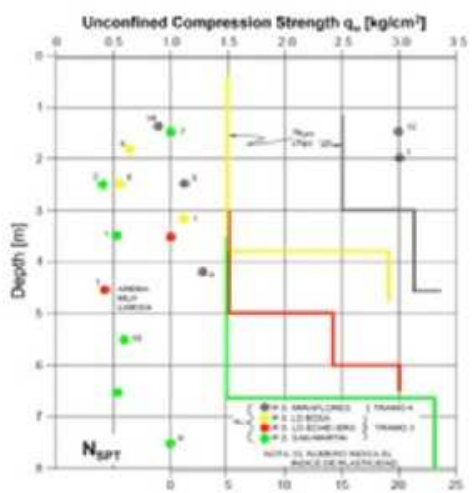

(d)

Figure 9. (a) Soil conditions at Paso San Martin $\left(33.3660^{\circ} \mathrm{S}, 70.6891^{\circ} \mathrm{W}\right)$, see Figure 5 ; (b) soil conditions at Paso Superior Lo Echevers $\left(33.3759^{\circ} \mathrm{S}, 70.7476^{\circ} \mathrm{W}\right)$, see Figure 6; (c) soil conditions at Paso Miraflores $\left(33.3945^{\circ} \mathrm{S}, 70.7700^{\circ} \mathrm{W}\right)$, see Figure 8 ; and (d) comparison of geotechnical site investigation data at the four overpass locations. Grey: Paso Miraflores (collapsed), Yellow: Paso Lo Bosa, Red: Paso Lo Echevers (collapsed), and Green: Paso San Martin.

role of site effects to the high concentration of damage, the dynamic response characteristics of the high-rise buildings are compared to estimates of the fundamental frequency of the local soil formations.

Bonnefoy et al. (2008) conducted extensive ambient vibration measurements in the basin of Santiago, Chile, evaluating the reliability of the horizontal-to-vertical amplitude spectra ratio method $(\mathrm{H} / \mathrm{V})$ as a tool to provide qualitative and quantitative information of site conditions in complex geological media. Results from this study showing the spatial distribution of the H/V peaks according to their frequencies are depicted in Figure 13: (red) 0.3-0.5, (blue) $0.51-1.2$, (yellow) 1.21-5 and (green) 5.1-10 Hz. Circles display frequencies for clear peaked H/V curves, whereas squares depict frequencies for peaks of low amplitude. The surface geology is shown in the background, while the black circle corresponds to the location of Ciudad Empresarial. As can be readily seen, the resonant frequencies at the site of the business park identified by means of $\mathrm{H} / \mathrm{V}$ ratios range from $0.5-5 \mathrm{~Hz}$, consistent with the structural resonant periods of the damaged structures. This is an indication 


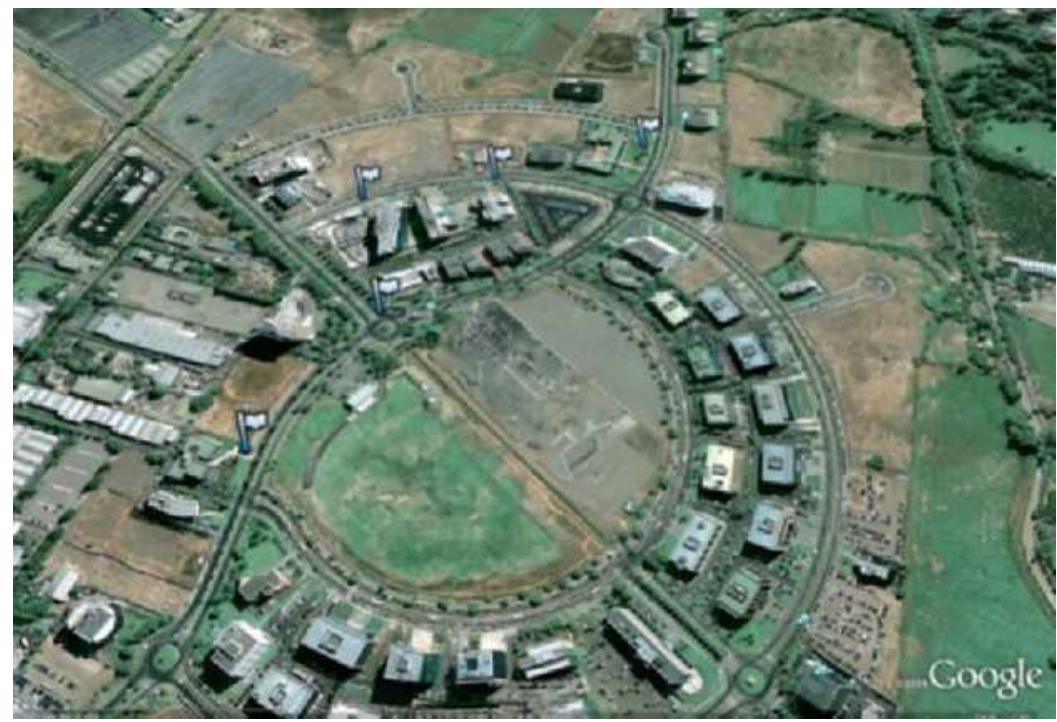

Figure 10. Aerial view of Ciudad Empresarial, depicting the structures that were inspected during reconnaissance.

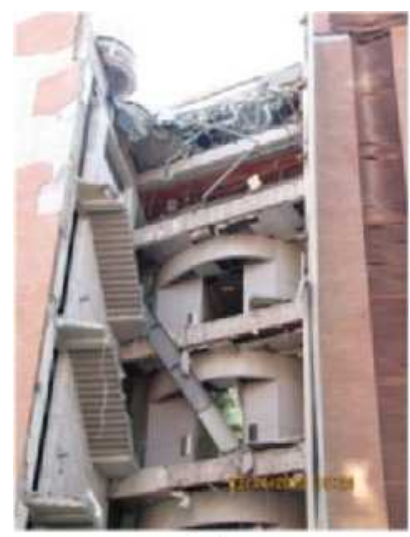

(a)

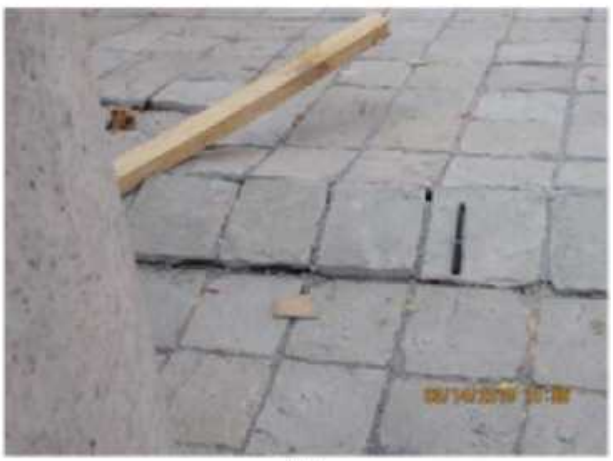

(b)

Figure 11. Six-story commercial building at $33.387985^{\circ} \mathrm{S}, 70.618815^{\circ} \mathrm{W}(1015 \mathrm{hrs}$ on $03 / 14 / 2010)$. (a) Damage of emergency staircase. (b) Evidence of ground deformation.

that site effects may have contributed to the concentrated structural damage at the site, while the strong structural damage variability at the site, with severely damaged structures adjacent to virtually undamaged ones has been partially attributed to the irregular structural configuration of the former. 


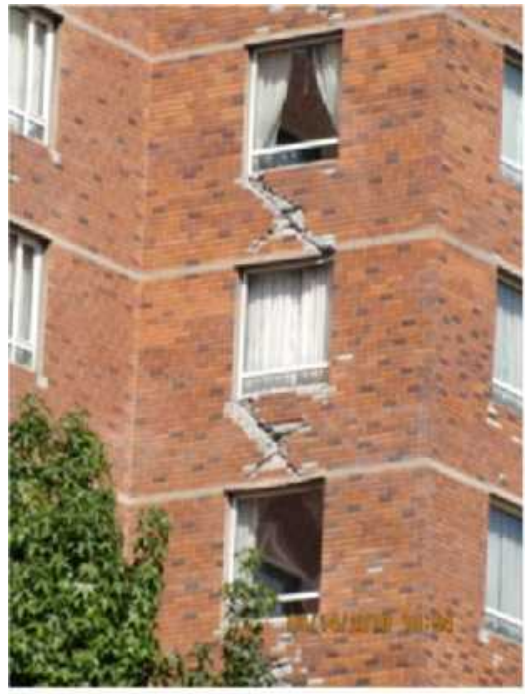

(a)

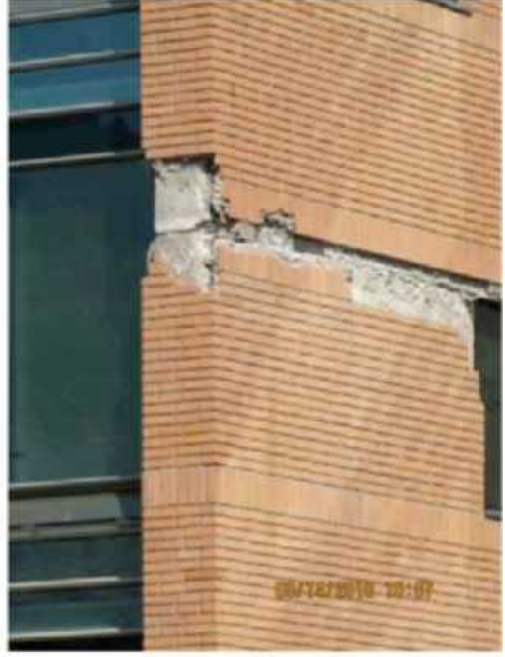

(b)

Figure 12. (a) Twelve-story building with severe structural damage $\left(33.387652^{\circ} \mathrm{S}, 70.617123^{\circ} \mathrm{W}\right.$, $1054 \mathrm{hrs}$ on $03 / 14 / 2010)$; and (b) Five-story building with severe structural damage $\left(33.389586^{\circ} \mathrm{S}\right.$, $70.618349^{\circ} \mathrm{W}, 1056 \mathrm{hrs}$ on $03 / 14 / 2010$ ).
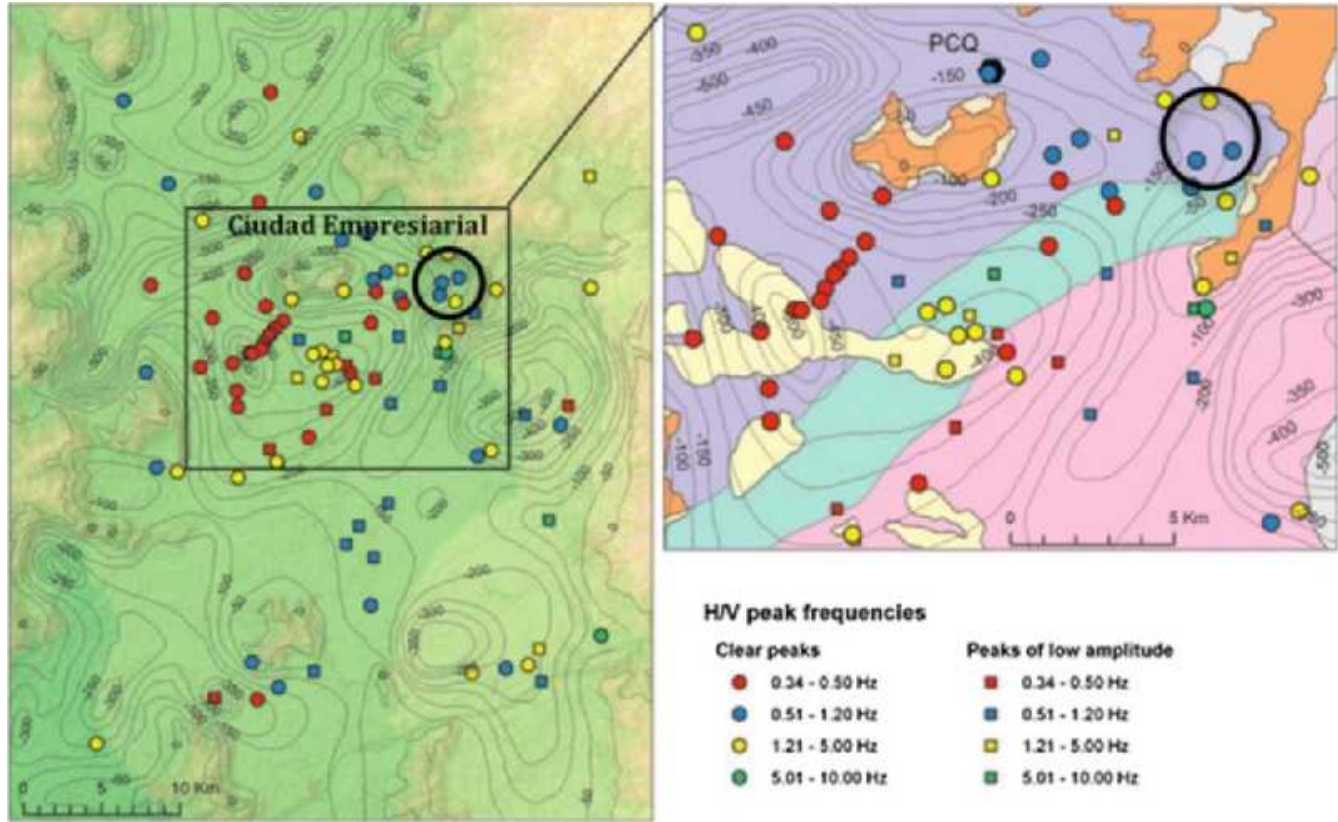

Figure 13. Spatial distribution of $\mathrm{H} / \mathrm{V}$ peaks from ambient noise measurements in NE Santiago, denoted according to their frequencies: (red) $0.3-0.5 \mathrm{~Hz}$, (blue) $0.51-1.2 \mathrm{~Hz}$, (yellow) $1.21-5 \mathrm{~Hz}$, and (green) $5.1-10 \mathrm{~Hz}$ (after Bonnefoy et al. 2008). Black circle corresponds to Ciudad Empresarial. 


\section{VIÑA DEL MAR}

The municipality of Viña del Mar is located in central Chile $\left(33^{\circ} 02^{\prime} \mathrm{S}, 71^{\circ} 34^{\prime} \mathrm{W}\right)$, adjacent to the city of Valparaíso, $120 \mathrm{~km}(75 \mathrm{mi})$ northwest of Santiago. The topography of Viña del Mar is typical of a receding coastline whose most notable features are marine terraces and sedimentary deposits (Figure 14a). Viña del Mar is founded on the marinealluvial deposits at the mouth of the Marga-Marga River; the site conditions can be divided into five main categories: (i) rock; (ii) weathered rock; (iii) cemented sand and gravel; (iv) uncemented sand and gravel; and (v) artificial fill. Weathered rock covers approximately $80 \%$ of the Viña del Mar region (Moehle et al. 1986), and the ground water table is located approximately $4 \mathrm{~m}$ below ground surface.

Viña del Mar was severely damaged during the 1985 Valparaíso earthquake; an extensive study on the structural damage observations can be found in Moehle et al. (1986). Strong motion recordings were obtained at the time both in Viña del Mar and the adjacent town of Valparaíso. Celebi (1991) studied the spectral ratios of the recorded motions and showed amplification by as much as a factor of 12 in the north-south direction within the frequency band $0.5-2 \mathrm{~Hz}$. This is consistent to a first approximation with the resonant frequencies of 5-20-story structures, typical of the structures that were severely damaged.

Immediately following the 1985 Earthquake, a microzonation study was conducted by the municipality of Viña del Mar, leading to the development of maps that identified the location of all existing buildings during the 1985 event, the damage distribution, and the location of demolished structures. Results from this study showed that, if an earthquake causes an intensity $I$ in the surrounding marine terraces, the intensity is likely to be

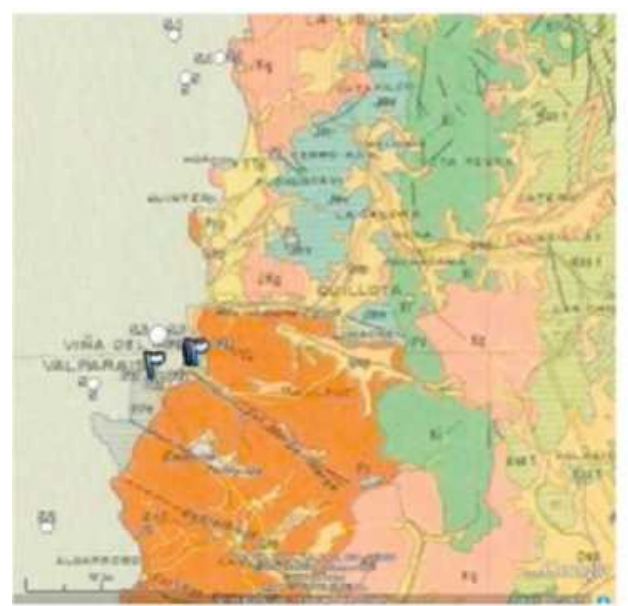

(a)

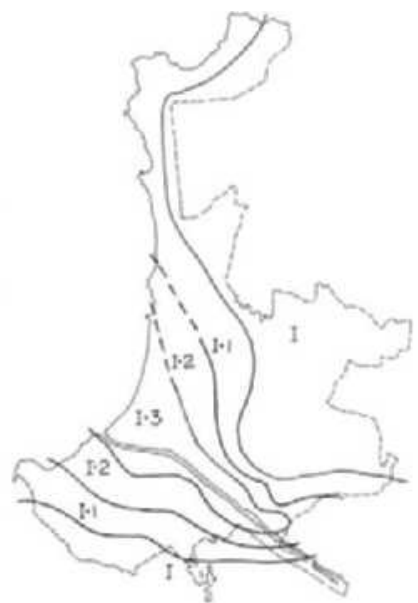

(b)

Figure 14. (a) Geology of the Viña del Mar/Valparaíso region, where the site conditions are described as weathered rock; (b) anticipated Modified Mercalli Intensity in the town of Viña Del Mar based on the river sediment geomorphology in the area (Moehle et al. 1986). 


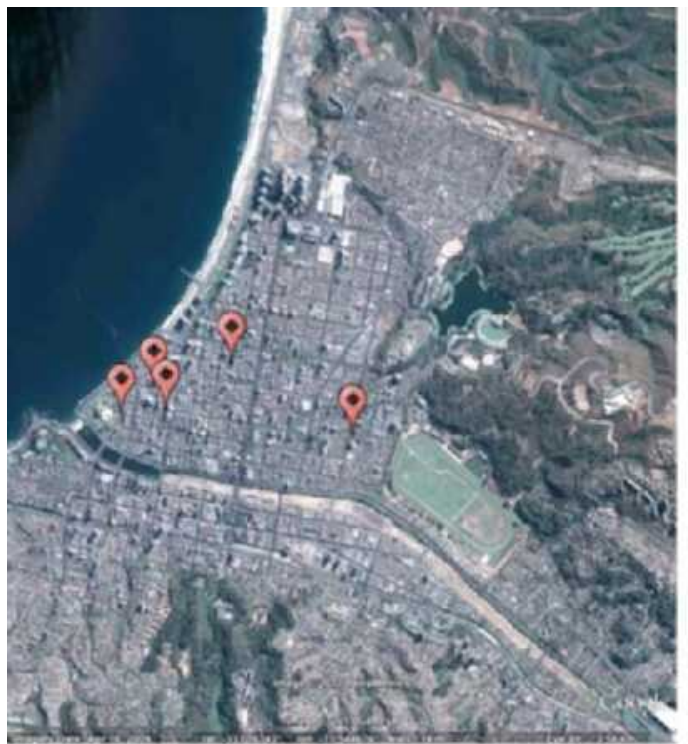

(a)

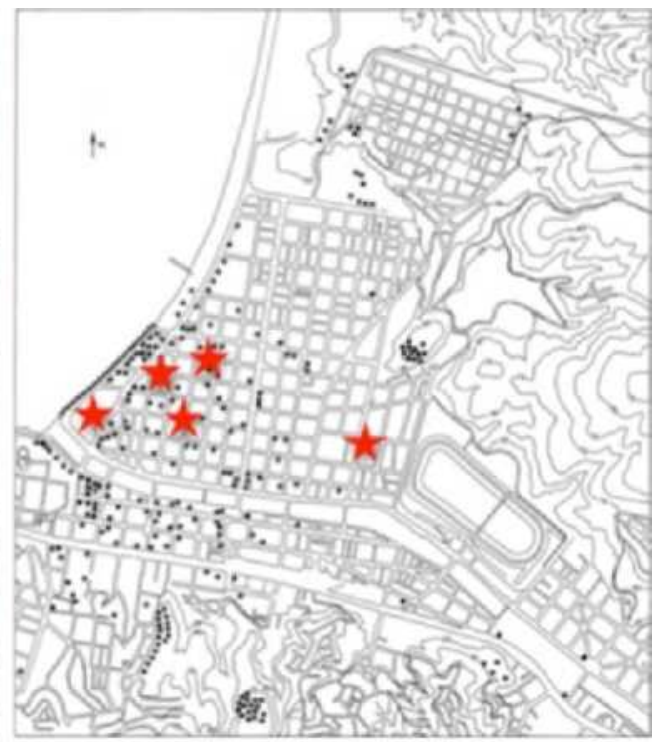

(b)

Figure 15. (a) Buildings inspected during reconnaissance in Viña del Mar. (b) Damaged buildings of five stories or higher, as mapped during microzonation study that followed the 1985 Valparaíso Earthquake (from Moehle et al. 1986). Note the similar concentration of damage in the southern part of the city, near the Marga-Marga river mouth in the two events.

$I+1$ and $I+2$ on the slopes leading down to the city and $I+3$ in the alluvial, fluvial, and colluvial deposits along the Marga-Marga River (Figure 14b).

Indeed, the same damage pattern was observed during reconnaissance of the 2010 event. Five severely damaged buildings were inspected, all located in the vicinity of the MargaMarga river mouth and thus founded on soft soil conditions. Note that during the microzonation study following the 1985 Earthquake, the Municipality of Viña del Mar mapped the location of buildings with 5 or more stories (Figure 15). The buildings inspected during reconnaissance after the 2010 Earthquake are shown on this map (also depicted on the aerial view of Google Earth), and are clearly located in the immediate vicinity of the river. Figure 16 depicts the structural damage observations of the reconnaissance team.

\section{CONCEPCIÓN}

The city of Concepción is built on Pleistocene to Holocene sediments filling a fluvial basin that is constructed in a paleotopography created by a horst-graben structure. This structure is associated to a set of NE-oriented normal faults that cut and displace a basement formed by Upper Cretaceous to Pliocene Sedimentary rocks on top of Upper Paleozoic granitic bodies (Galli, 1967; Vivallos et al. 2010). The geological map of the area and a typical geological NW-SE cross section (i.e., perpendicular to the main structures) are shown in Figure 17. This section and the geological map show the sedimentary in-fill of the basin and its structural relationship with the 3 major crustal faults that run through the area. 

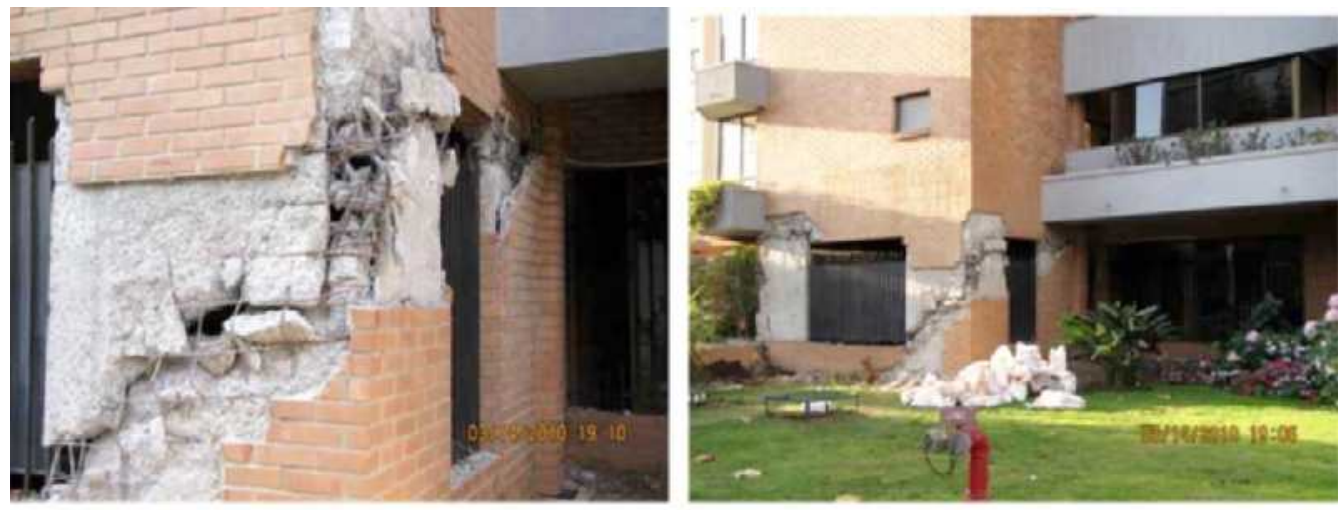

(a)
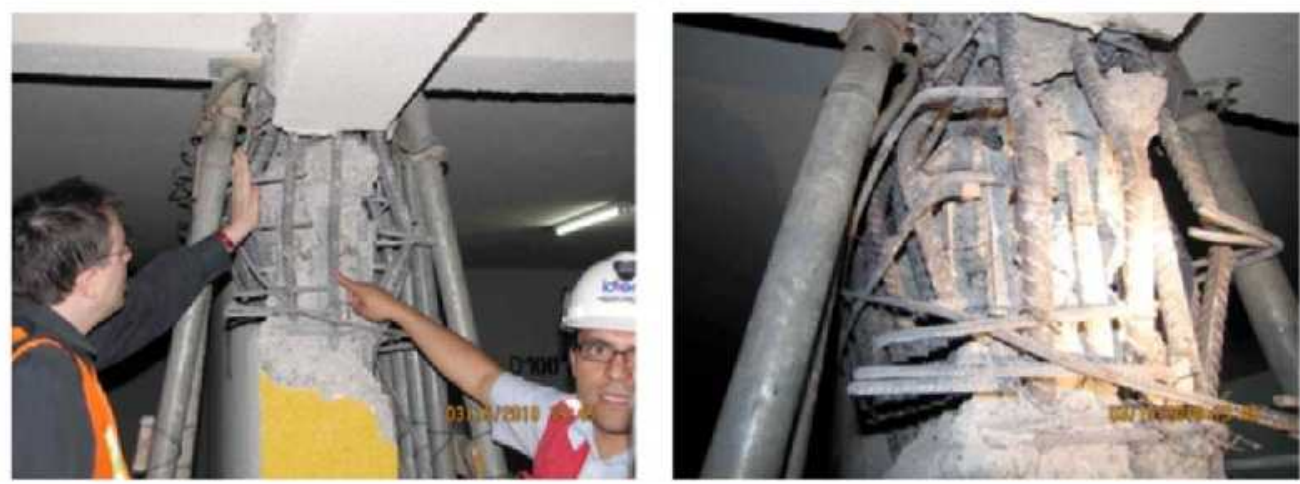

(b)

Figure 16. (a) Damaged 10-story building $\left(33.016045^{\circ} \mathrm{S}, 71.551990^{\circ} \mathrm{W}, 1916 \mathrm{hrs}\right.$ on $\left.03 / 14 / 2010\right)$ due to lack of confinement at the beam-column joints and low quality concrete; and (b) heavily damaged 20 -story building due to lack of confinement at the beam-column joints $\left(33.020074^{\circ} \mathrm{S}\right.$, $71.544055^{\circ} \mathrm{W}, 1945 \mathrm{hrs}$ on $\left.03 / 15 / 2010\right)$.

Concepción was severely hit by the earthquake of 27 February 2010, and the extensive damage in the downtown area is potentially associated with site and/or basin effects. Indeed, the damage pattern observed during the 2010 event was very similar to the distribution during the 1960 earthquake, for the most part concentrated in the downtown (Galli et al. 1963); in both events, the bridges across the Bío-Bío River collapsed. Focusing on the 2010 event, Concepción had seven distinct zones in which buildings and/or bridges collapsed catastrophically. Six of these seven zones are longitudinal in shape and oriented somehow parallel to the major faults that form the basin configuration (Figure 18). The damage is primarily correlated with the location of old lagoons that were artificially filled (non-engineered) to increase usable surface on the city (Galli, 1967), similarly to the Texcoco lake in Mexico on which Mexico city was subsequently founded; strong correlation was also noted between the thickness of the sediments and the level of structural damage (Vivallos et al. 2010). La Pólvora Fault (see Figure 19) defines the northwest edge of the south sub-basin 


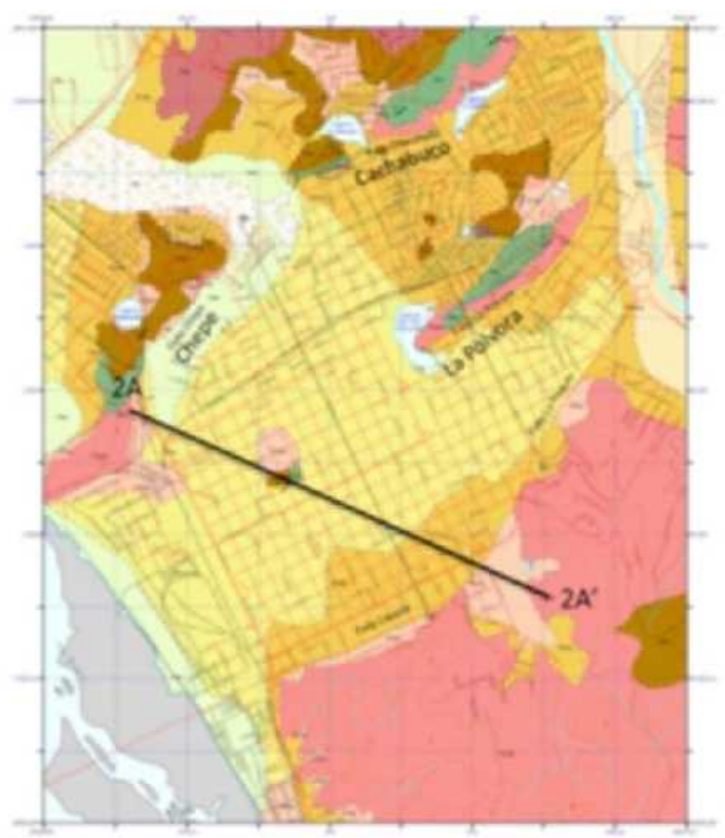

(a)

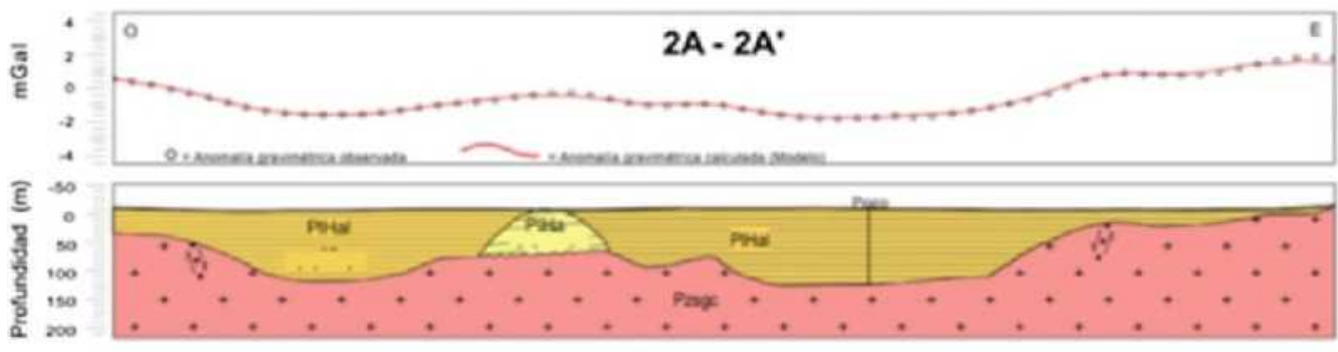

(b)

Figure 17. (a) Geologic map of Concepción downtown area (adapted from Vivallos et al. 2010). Red are Paleozoic granitoids, green are Upper Cretaceous sedimentary rocks, dark brownish are Paleocene sedimentary rocks, light brownish and yellow are Pliocene to Holocene sedimentary deposits that fill the Cancepcion basin. (b) Geological cross-section used as forward density model to fit the observed gravity anomaly.

where the majority of the buildings are located; the rest of the damage in Concepción was on the Tertiary sediments between the La Pólvora Fault on the north, the Chacabuco Fault to the south and the Lo Pequén Fault to the east.

The fundamental periods for 46 surveyed buildings after the event were calculated by Giuliano and Parodi (2011). The average period for the structures that suffered extreme damage is $0.68 \mathrm{~s}$; for the severely damaged ones is $0.50 \mathrm{~s}$; for the moderately damaged $0.38 \mathrm{~s}$; and for the low to no damaged ones is $0.37 \mathrm{~s}$. Hence, the softer soils on or near 


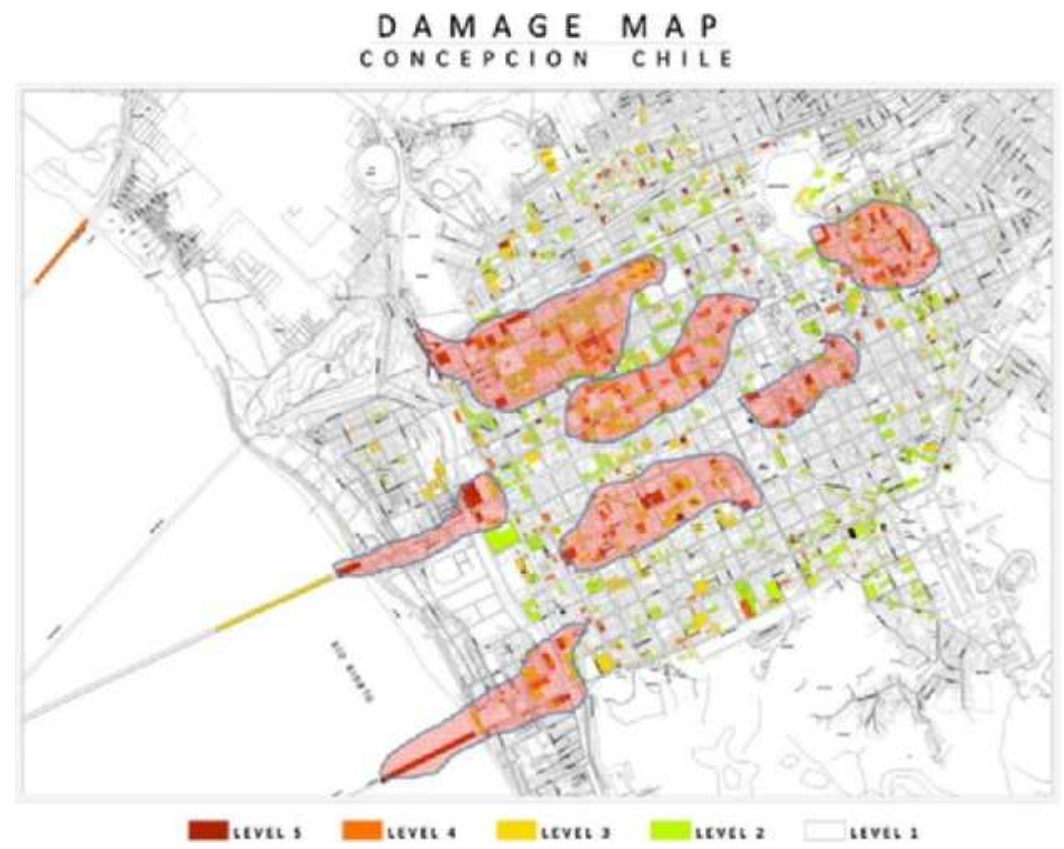

Figure 18. Damaged sections in downtown Concepción; six out of seven are parallel to major faults.

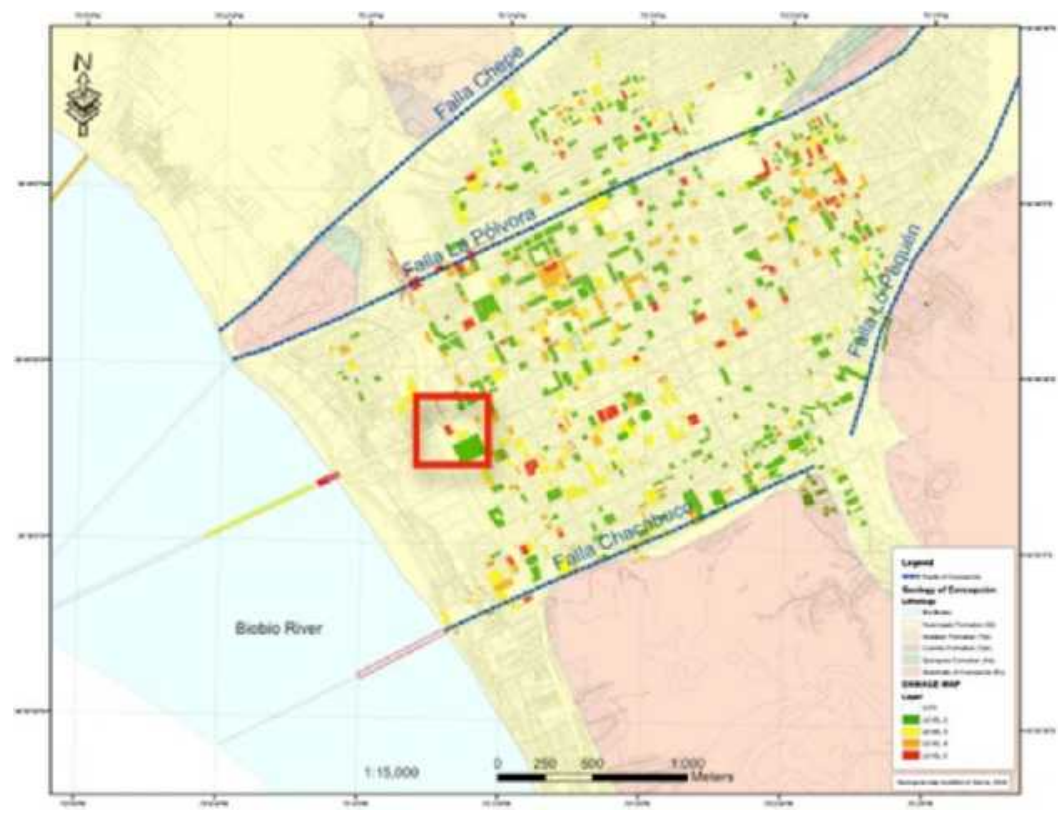

Figure 19. Inspected buildings and damage level in downtown Concepción, superimposed on geology map of the region. Red box depicts the location of two adjacent buildings, one collapsed $\left(36.8279^{\circ} \mathrm{S}, 73.0616^{\circ} \mathrm{W}\right)$ and one that suffered minor damage $\left(36.8280^{\circ} \mathrm{S}, 73.0607^{\circ} \mathrm{W}\right)$, further described in Figures 20 and 21. 

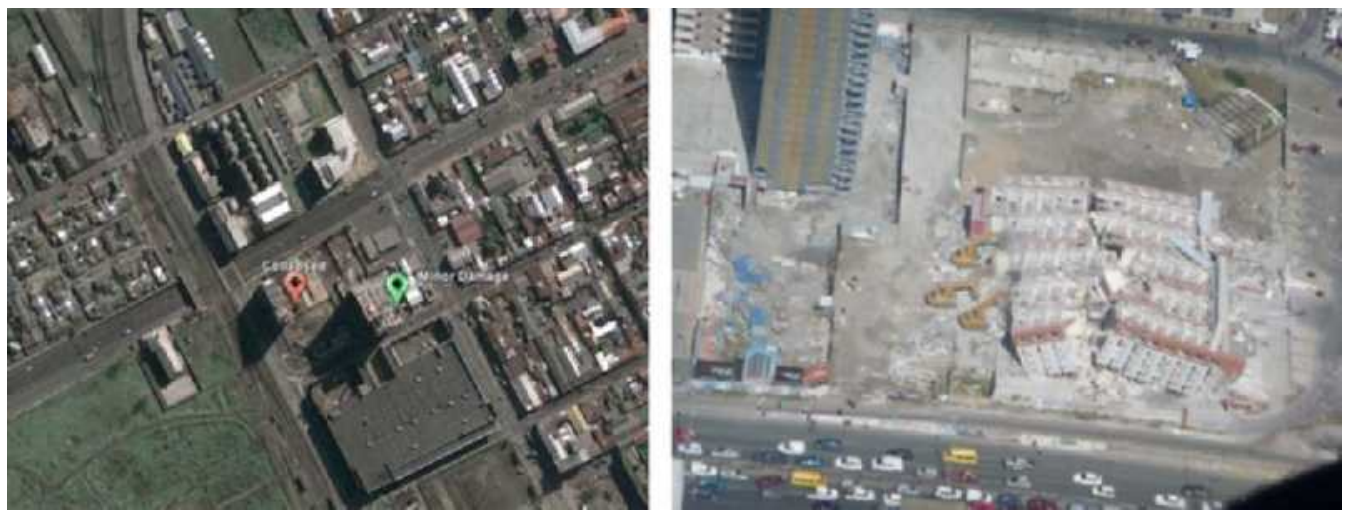

Figure 20. Locations of two adjacent buildings (see Figure 21) designed with using different site conditions and consequently different foundation types in Conception (map and aerial view).

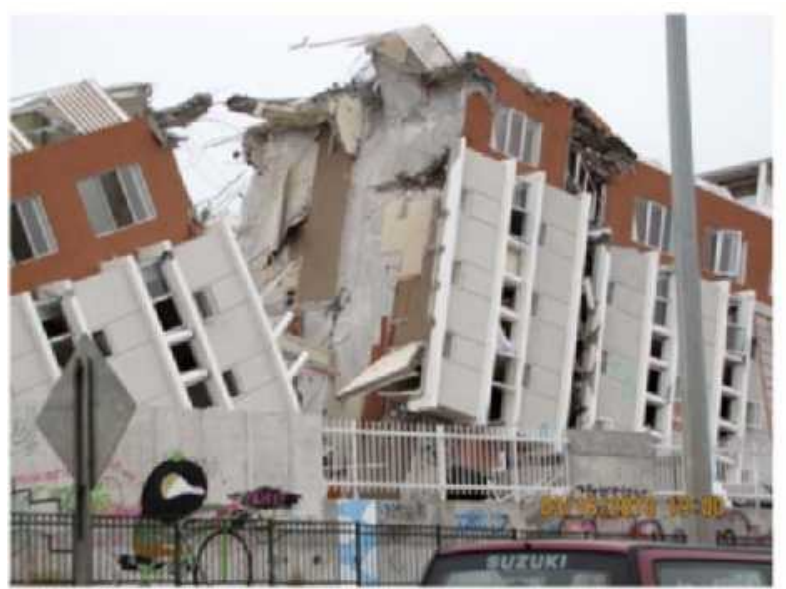

(a)

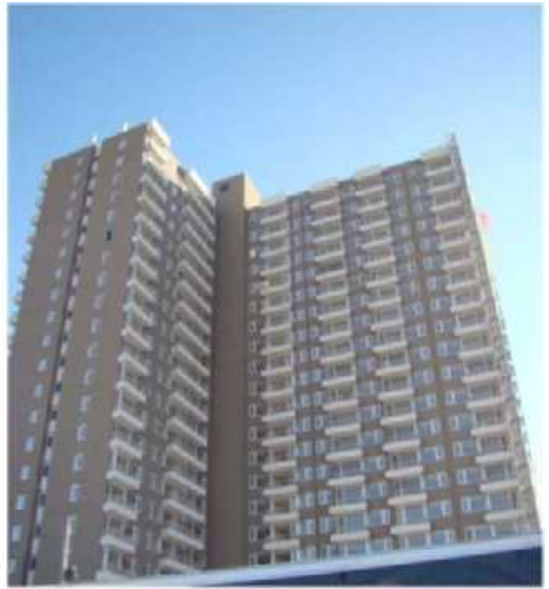

(b)

Figure 21. (a) Fifteen-story collapsed structure $\left(36.828067^{\circ} \mathrm{S}, 73.061639^{\circ} \mathrm{W}, 1900 \mathrm{hrs}\right.$ on 03/16/2010) designed using Soil Type II conditions; and (b) 20-story structure adjacent to collapsed $\left(36.828083^{\circ} \mathrm{S}, 73.060600^{\circ} \mathrm{W}, 1910 \mathrm{hrs}\right.$ on $\left.03 / 16 / 2010\right)$ designed using Soil Type III conditions, and suffering only minor damages.

the artificial fills combined with longer period structures contributed to the increase in structural performance demand and the consequent severe structural damage.

A striking example of the role of site conditions and soil-structure interaction in the seismic performance of structures is described below. Two adjacent multi-story structures were inspected during reconnaissance close to the Llacolén bridge in downtown Concepción (see location in Figure 19), one fully collapsed during the 2010 event and the other suffered minor damage and is currently being repaired. The 15-story collapsed building (Alto Rio) was designed using Site Type II (Chilean design code) on shallow foundation, and the one that did not collapse using Site Type III on pile foundations, which implies a higher design spectrum. While there is no evidence that the soil conditions are indeed different at the 
locations of the two structures (distance between them of approximately $20 \mathrm{~m}$ ), the difference in design spectra values may have played an important role in the failure of the building; according to the Chilean design code, the design spectral value for Type III soil conditions relative to Type II is 2.78 for period $T=1 \mathrm{~s}$ and 2.47 for period $T=2 \mathrm{~s}$. The locations of the two buildings are depicted in Figure 20.

Overall, damage in Concepción was observed mainly on the valley, while the damage intensity on the hillsides was lower. This suggests that topographic amplification was not a predominant cause of damage at this location. While this does not imply that topography effects did not play a role in the damage distribution, it does suggest that if they did, it was less relevant to seismic demand than the stiffness of the subsurface sediments or basin effects.

\section{SUMMARY AND CONCLUSIONS}

A suite of observations on damage patterns and site effects following the Great 2010 Chile earthquake were discussed. These observations focus on identification of structural damage variability associated with non-uniform soil conditions and subsurface geology in three severely affected regions: (1) the metropolitan area of Santiago (Américo Vespuccio Norte Ring Highway, Ciudad Empresarial Business Park), (2) the municipality of Viña del Mar, and (3) the city of Concepción. As these regions are separated by distances as high as $600 \mathrm{~km}$ along the Chilean coast and are located more than 30-40 kilometers away from the fault, it is believed that observed concentration of damage is likely to reflect primarily site than source or other seismological/engineering effects. The following conclusions were drawn:

1. Given that soil conditions at the piers of the four collapsed bridges in Américo Vespucio Norte highway in Santiago appear to be rather uniform, the question as to what contributed to the highly variable damage along the highway remains open. Possible explanations relate to the geometry of the basin and the geology of deep sediments, as well as minor exceedance/ nonexceedance of design loads in brittle structural components.

2. Ciudad Empresarial Business Park was severely damaged, with seven five- to sevenstory buildings that suffered severe damage and were closed to the public. Extensive ambient vibration measurements conducted before the earthquake by means of $(\mathrm{H} / \mathrm{V})$ ratios, showed resonant frequencies at the site ranging from $0.5-5 \mathrm{~Hz}$, consistent with the resonant periods of the damaged structures. Nevertheless, why the specific structures experienced severe damage while others at the site, of similar general characteristics, were undamaged is harder to explain and may be related to structural factors.

3. In Viña del Mar, five severely damaged high-rise buildings were inspected, all located in the vicinity of the Marga-Marga river mouth, founded on very soft soil. Results from the investigation following the 1985 earthquake showed very similar concentration of damage. If an earthquake causes an intensity $I$ in the surrounding marine terraces, the intensity is likely to $I+3$ in the alluvial, fluvial, and colluvial deposits along the Marga-Marga River. The correlation between site condition and structural damage in this area cannot be overstated. 
4. In Concepción, the extensive damage in the downtown area has been associated with site and/or basin effects. There is evidence that the damage pattern observed during the 2010 event was very similar to the distribution during the 1960 earthquake, for the most part is concentrated in the downtown. In both events, the bridges across the Bío-Bío River (mostly founded on soft, liquefaction susceptible, ground) collapsed. In the 2010 event, Concepción had seven distinct zones in which buildings and/or bridges failed catastrophically. The damage is primarily correlated with the presence of very soft soils in the vicinity or on the surface of artificial fill.

\section{ACKNOWLEDGMENTS}

This material is based upon work supported by the National Science Foundation (NSF) under Grant No. CMMI-1034831. Any opinions, findings, and conclusions or recommendations expressed in this material are those of the authors and do not necessarily reflect the views of the NSF. Additional support was provided by Golder Associates and the Chilean Air Force. All GEER team members contributed to this effort, including Jonathan Bray, David Frost, Ramon Verdugo, Christian Ledezma, Terry Eldridge, Pedro Arduino, Scott Ashford, Dominic Assimaki, David Baska, Jim Bay, R. Boroschek, Gabriel Candia, Leonardo Dorador, Aldo Faúndez, Gabriel Ferrer, Lenart Gonzalez, Youssef Hashash, Tara Hutchinson, Laurie Johnson, Katherine Jones, Keith Kelson, Rob Kayen, Gonzalo Montalva, Robb Moss, Sebastian Maureira, George Mylonakis, Scott Olson, Kyle Rollins, Nicholas Sitar, Jonathan Stewart, Mesut Turel, Alfredo Urzúa, Claudia Welker, and Rob Witter.

\section{REFERENCES}

Arduino, P., Ashford, S., Assimaki, D., Bray, J., Eldridge, T., Frost, D., Hutchinson, T., Johnson, L., Kelson, K., Kayen, R., Ledezma, C., Montalva, G., Moss, R., Mylonakis, G., Olson, S., Rollins, K., Sitar, N., Stewart, J., Urzua, A., Verdugo, R., Witter, R., and Zoa, N., 2010. EERI special earthquake report: The M8.8 Maule, Chile, earthquake of 27 February 2010 Learning from Earthquakes, EERI Newsletter, June 2010, Earthquake Engineering Research Institute, Oakland, CA.

Astroza, M., and Monge, J., 1987. Zonificacion sismica de la ciudad de Santiago, in Proceedings of the XXIV Jornadas Sudamericanas de Ingeneria Estructural 5, Porto Alegre, Brasil, 29 June-3 July, ANAIS, 221-235.

Astroza, M., and Monge, J., 1991. Seismic microzones in the city of Santiago. Relation damagegeological unit, in Proceedings of the Fourth International Conference on Seismic Zonation, Vol. 3, Stanford, CA, USA, August 25-29, Earthquake Engineering Research Institute, Oakland, CA, 595-601.

Astroza, M., Monge, J., and Valera, J., 1993. Intensidades del sismo del 3 de marzo 1985 en la region metropolitana y el litoral central, in Ingeneria sismica, el caso del sismo del 3 de marzo 1985, Instituto Ingenieros de Chile, Ediciones Pedagogicas Chilenas S.A., Ediciones Dolmen, 103-117 (in Spanish).

Bonnefoy-Claudet, S., Baize, S., Bonilla, L. F., Berge-Thierry, C., Pasten, C., Campos, J., Volant, P., and Verdugo, R., 2008. Site effect evaluation in the basin of Santiago de Chile using ambient noise measurements, Geophys. J. Int.

Boroschek, R., Contreras, V., Kwak, D. Y., and Stewart, J. P., 2012. Strong ground motion attributes of the $2010 \mathrm{M}_{\mathrm{w}} 8.8$ Maule, Chile, earthquake, Earthquake Spectra 28, this issue. 
Bravo, R. D., 1992. Estudio geofisico de los suelos de fundacion para un zonificacion sismica del area urbana de Santiago Norte, Ph.D. Thesis, Universidad de Chile, Santiago.

Bray, J., Frost, D., Verdugo, R., Ledezma, C., Eldridge, T., Arduino, P., Ashford, S., Assimaki, D., Hutchinson, T., Johnson, L., Kelson, K., Kayen, R., Montalva, G., Moss, R., Mylonakis, G., Olson, S., Rollins, K., Sitar, N., Stewart, J., Urzua, A., Witter, R., and Zoa, N., 2010. GeoEngineering Reconnaissance of the 27 February 2010 Maule, Chile Earthquake, Report of the National Science Foundation-Sponsored Geoengineering Extreme Events Reconnaissance (GEER) Team, April 2010.

Celebi, M., 1991. Topographical and geological amplification: Case studies and engineering applications, Structural Safety 10, 199-217.

Fernandez, J. C., 2003. Respuesta sísmica de la cuenca de Santiago, region metropolitana de Santiago, Escala 1:100000, 1 mapa, SERNAGEOMIN, carta geologica de Chile, Serie Geologia Ambiental (Environmental Geology), No. 1, ISSN:0717-7305.

Galli, C., 1967. Geología urbana y suelos de fundación de Concepción y Talcahuano, Informe final del proyecto de investigación $\mathrm{N}^{\circ} 75$ de la Universidad de Concepción. $248 \mathrm{pp}$.

Galli, C., Sanchez, R. J., and Saint-Amand, P., 1963. Effects of the earthquakes of May 1960 in Concepción and vicinity, Bulletin of the Seismological Society of America 53, 1281-1297.

Giuliano, M., and Parodi, C., 2011. Vulnerability index for R.C. buildings, an application to the case of Concepción (Chile), to be submitted to Earthquake Spectra.

Gueguen, P., 1994. Microzonage de Santiago du Chile (technique de Nakamura), M.S. Thesis, Joseph Fourier University, Grenoble, France (in French).

International Building Code (IBC), 2006. International Building Code, New Jersey Edition.

Iriarte-Diaz, S., 2003. Impact of Urban Recharge on Long-Term Management of Santiago Norte aquifer, Santiago-Chile, M.S. Thesis, Waterloo University, Ontario, Canada.

Ledezma, C., 2011. Personal communication.

Moehle, J., Wood, S., and Wight, J., 1986. The 1985 Chilean Earthquake: Observations of Earthquake-Resistant Construction in Viña del Mar, Report to the National Science Foundation, Research Grants ECE 86-03789, ECE 86-03604, and ECE 86-06089.

Monge, J., 1986. El sismo del 3 de marzo 1985, Chile, Second Edition, Acero Comercial, Santiago de Chile, Chile (in Spanish).

Morales-Jerez, F. R., 2002. Definición de Aquíferos en la Cuenca del Río Maipo, M.S. Thesis, University of Chile, Santiago de Chile (in Spanish).

Valenzuela, G. B., 1978. Suelo de Fundación del Gran Santiago, Instituto de Investigaciones Geológicas, Chile, 1-27 (in Spanish with English abstract).

Valenzuela, M., Bonilla, R., Neumann, A., and Montalva, G. A., 2007. Seismic soil classification for the Concepción-Talcahuano Area According to Nch 433, VI Chilean Geotechnical Conference (in Spanish).

Vivallos, J., Ramírez, P., and Fonseca, A., 2010. Microzonificación sísmica de la ciudad de Concepción, Región del Biobio, Servicio Nacional de Geología y Minería, Carta Geológica de Chile, Serie Geología Ambiental 12, 3 mapas en una hoja escala 1:20.000. Santiago.

(Received 14 March 2011; accepted 4 February 2012) 